\title{
Managing Longevity Risk: The Need for Financial Literacy and the Role of the Financial Advisor
}

\section{Jacqueline Volkman-Wise*}

Temple University, Department of Risk, Insurance \& Healthcare Management, 619 Alter Hall, 1801 Liacouras Walk, Philadelphia, PA 19122, USA

Over the last several decades, there has been a movement in retirement saving plans offered by employers from Defined Benefit (DB) to Defined Contribution (DC). In DB plans, the plan sponsor promises workers a specified annuity benefit for their retirement, is liable for such a promise, and is responsible for asset management of funds in the plan. DC plans allow employees to decide in which assets their retirement investment will be allocated. Investment choice, within a menu offered by the sponsor, and capital market risk is moved from the employer to the employee in this plan.

The introduction of DC plans to retirement saving has been of great concern lately. Even though it is believed that longevity risk should be managed by individuals pre-retirement, the introduction of DC plans has also shifted investment risk to individuals which is something they may not be able to manage well [1]. Recent capital market volatility has affected the performance of many plan participants' portfolios, and the data shows that individuals do not appropriately save for retirement [2]. Therefore, it is important to understand how financially literate individuals are so that they can better manage this risk and what resources are available to help them with such management.

Recent research indicates there is a lack of financial literacy. A majority of Gen X and Gen Y consumers admit that they have little to no knowledge of investments and products [3] and evidence shows individuals consistently make errors with regard to financial decisions leading to significant financial consequences sometimes. For instance, Choi et al. [4] find that in the U.S., 36\% of employees over $59 \frac{1}{2} 2$ years old who have a 401(k) plan from their employer, are fully vested, and are eligible for an employer match do not participate in the plan at all or contribute less than that which would give them the full employer match.

This behavior causes the employees to forego $1.6 \%$ of their annual pay in matching contributions from the

employer which lowers their ability to save for retirement, and the cumulative loss will likely be much larger. It is interesting that employees act in such a way, given they can immediately withdraw the contribution from the account penalty-free if they wanted given their age. A lack of understanding of pensions and finances seems to be motivating such behavior.

Financial illiteracy is demonstrated not just in $401(\mathrm{k})$ participation but in many other facets of financial decision-making. Many investors, including well-educated ones, when choosing among four different S\&P 500 Index funds in an experiment fail to choose the fund which has the lowest fees, despite the fact that the investment objective is the same for all four funds so the only distinguishing difference is the fees [5]. Other financial mistakes that have been documented include low level of stock market participation, inadequate diversification due to a preference to invest in local firms and employer stock, and a tendency to sell assets that have appreciated while holding assets which have declined $[6,7]$.

${ }^{1}$ See Dodd-Frank Wall Street Reform and Consumer Protection Act. H. R. 4173. Title X - Bureau of Consumer Financial Protection 2010, Section 1013.
Households' limited financial knowledge has become such a concern that within the Dodd- Frank Wall Street Reform and Consumer Project Act which was signed into law in July 2010, the Consumer Financial Protection Bureau (CFPB) was created and charged with establishing an Office of Financial Education. The goal of this office is to "develop a strategy to improve the financial literacy of consumers."1 Increased financial literacy should help with retirement planning. Financial literacy has been shown to be positively associated with retirement planning behavior [8-12], and respondents with more confidence in their financial knowledge have a higher propensity to plan [13]. This improvement is needed as preparing for retirement is a burden borne more and more by the individual and research shows there is limited pension knowledge among individuals [2,9]. The lack of financial literacy and pension knowledge will ultimately impact a household's ability to appropriately save for retirement. Limited financial knowledge has been shown to affect household net worth [13] and impact a household's ability to effectively plan and save for retirement. With the movement from defined benefit to defined contribution employersponsored pension plans, retirement savings is becoming ever more the responsibility of individuals. Evidence suggests financial knowledge is a key component to being able to manage longevity risk and maintain economic security in retirement. Therefore, there is an increasing need for financial education and advice in the marketplace.

But what exactly does the market for financial advice look like? Is the way that it currently operates in the best interest of consumers? Many employers sponsoring a retirement plan to their employees offer sessions where employees can meet with a representative from the financial institution managing the retirement plan. Such sessions are aimed at helping employees with decisions regarding saving and investing for retirement. But just how useful are these sessions? With regard to financial advice from the market in general, the role of the financial advisor has shifted over time. Now this individual not only offers advice on how to properly save and invest, but also does the investing for the client many times. In this manner, one individual can act as both a financial advisor and a broker. So how are these individuals regulated? A financial advisor should act in the best interest of his/her clients and should be held to a higher fiduciary and ethical responsibility than an investment broker; brokers, on the other hand, have an incentive to invest in securities maintained by the financial

*Corresponding author: Jacqueline Volkman-Wise, Temple University, Department of Risk, Insurance \& Healthcare Management, 619 Alter Hall, 1801 Liacouras Walk, Philadelphia, PA 19122, USA, Tel: 1-215-204-6826; Fax: 1-215-204-4712; E-mail: jacqueline.wise@temple.edu

Received March 23, 2013; Accepted March 25, 2013; Published March 27, 2013

Citation: Volkman-Wise J (2013) Managing Longevity Risk: The Need for Financial Literacy and the Role of the Financial Advisor. J Bus \& Fin Aff 2: e133. doi:10.4172/2167-0234.1000e133

Copyright: @ 2013 Volkman-Wise J. This is an open-access article distributed under the terms of the Creative Commons Attribution License, which permits unrestricted use, distribution, and reproduction in any medium, provided the original author and source are credited. 
institution for which he or she works. But would those securities be in the best interest of the client? Is there a conflict of interest potentially?

With regard to the information sessions offered by employers, the evidence seems to suggest that while these sessions help employees participate in an employer-sponsored retirement plan they do not necessarily help in such a way that longevity risk is properly managed for the household. Increasing employee participation in the plan is certainly beneficial as it increases employees' savings for retirement through increased employee contributions. Yet, plan design aspects such as automatic enrollment and prescriptive savings plans seem to have a greater impact on increasing savings for retirement than financial advising sessions [14]. Additionally, such informational seminars focus entirely on the employer- sponsored retirement plan. In order to adequately prepare for retirement, individuals need increased literacy on their entire retirement savings portfolio. Therefore the true benefit of financial education in the workplace through retirement seminars for employer-sponsored retirement plans is unclear. ${ }^{2}$ Consequently, the need for further advice requires households to go to the market seeking financial advisors there.

As mentioned earlier, there are growing concerns regarding the role of the financial advisor in the marketplace and whether currently they are always operating in the best interest of the client. Over time, brokers have increasingly acted more as financial advisors, especially once increased competition arose after the deregulation of fixed commissions in 1975. This concern of brokers acting as advisors is ever more important as more households demand financial advice and become increasingly responsible for their own retirement savings. Some of the potential conflict associated with financial advice stems from the different regulation of financial advisors

and brokers; that is, different oversight exists for a broker compared to that for a financial advisor. Brokers are regulated under the Securities and Exchange Act of 1934 which holds brokers to a "suitability" standard; investments recommended by a broker must be suitable for the client's needs. Financial advisors are regulated under the Investment Advisors Act of 1940 which stipulates advisors must meet a "fiduciary" standard of care. This standard is higher than that of suitability standard for brokers as under the fiduciary standard, the advisor's investment recommendation must be both suitable for the client's needs and in the client's "best interest."

It is important that households be able to obtain advice that is in their best interest. Unfortunately, it seems that even the financial advisors often act in their own best interest. Mullainathan et al. [22] audit financial advisors working for a bank, retail investment firm, or independent advising company that focuses on the lower end of the retail segment in Boston. The authors find that many advisors push investments that align with their own incentives regardless of which investments best meet the client's preferences; that is, many of them promote active-management portfolios. Additionally the advisors reinforce a bias a client might have when it benefits the advisor; for instance, advisors further support investment in employer stock if it benefits the advisor even if it causes too low of diversification for the client. If an advisor was truly offering a fiduciary standard of care he or she would not encourage too much investment in employer stock.

Because of the conflicts that exist in the marketplace for financial advice, it is important that policy be amended. Should there be one regulation of brokers and financial advisors though? The current debate by policymakers is that some sort of amendment is needed, but it should not be done at the cost of market liquidity. Brokers offer an important function with regard to this and holding them to too high of a standard could inhibit this key role they play in the market. Although brokers most likely need some sort of increased regulation as their roles have more a financial advisor aspect, they at least do have a Self-Regulatory Organization (SRO) and are monitored by FINRA. On the other hand, financial advisors have no such SRO to monitor their activity. This lack of oversight might explain why such behavior as that documented by Mullainathan et al. [22] occurs. In addition to the resolution of the regulatory standard for financial advisors versus brokers, regulatory oversight is needed for financial advisors in general.

No matter the regulation amendments that occur, those offering financial advice should be required to be more transparent in their fees to clients. If consumers knew how such advisors were rewarded more for promoting certain investments, it would help consumers know how much they should value the advice they are given. Similarly it would open the door for increased competition and the emergence of more financial advisors that are not associated with a particular investment company. Such advisors would be more apt to provide independent advice that is in the best interest of the client. Such initiatives as increased regulation for brokers, a SRO for financial advisors and increased transparency would aid in making the market for financial advice operate more efficiently. It would also improve households ability to obtain quality financial advice and consequently manage their longevity risk more effectively.

The management of longevity risk is a critical issue; employers are increasingly offering DC rather than DB pension plans. Although DC plans allow employees more flexibility in maintaining their pension wealth, they also cause employees to bear market risk. In fact previous work shows that having an opportunity to switch back to a DB plan from a DC plan is sometimes optimal for employees as the risk associated with DC plans can have real impacts on retirement wealth $[23,24]$. As such, it is important to understand how individuals make financial decisions and the environment in which they are obtaining financial advice. Financial literacy is critical to individuals managing their longevity risk and to date, it appears most individuals are not well-educated in this domain. Even though there is some evidence that financial literacy can improve through a learning-by- doing mechanism [25], financial decisions associated with saving and investing for retirement are done intermittently and have delayed outcomes. Learning-by-doing may not improve financial knowledge in these situations then [26]. Consequently, many households will be relying on advice from professionals to help them manage their longevity risk. It is imperative that we ensure these professionals have the proper incentives to act on the behalf of their clients and that the regulations are set so as to maintain these aligned incentives.

\section{References}

1. Turner A (2006) Pensions, Risks, and Capital Markets. Journal of Risk and Insurance 4: 559-574.

2. Bernheim D, Skinner J, Weinberg S (2001) What Accounts for the Variation in Retirement Wealth Among U.S. Households? American Economic Review 91: 832-857.

3. Life Insurance and Market Research Association (LIMRA) Majority of Gen X and Gen Y Ameriacans are Uniformed About Investments and Financial Products.

4. Choi J, Laibson D, Madrian BC (2011) \$100 Bills on the Sidewalk: Suboptimal Investment in 401(k) Plans. Review of Economic Statistics 3: 748-763. 
Citation: Volkman-Wise J (2013) Managing Longevity Risk: The Need for Financial Literacy and the Role of the Financial Advisor. J Bus \& Fin Aff 2: e133. doi:10.4172/2167-0234.1000e133

5. Choi J, Laibson D, Madrian BC (2009) Why Does the Law of One Price Fail? An Experiment on Index Mutual Funds. Review of Financial Studies 4: 1405-1432.

6. Campbell JY (2006) Household Finance. Journal of Finance 4: 1553-1604

7. Odean T (1998) Are Investors Reluctant to Realize Their Losses? Journal of Finance 5: 1775-1798.

8. Lusardi A (1999) Information, Expectations, and Savings for Retirement. In Aaron $\mathrm{H}$ (Ed.) Behavioral Dimensions of Retirement Economics, Brookings Institution Press and Russell Sage Foundation, Washington, DC, USA

9. Lusardi A, Mitchell OS (2007) Baby Boomers Retirement Security: The Role of Planning, Financial Literacy, and Housing Wealth. Journal of Monetary Economics 54: 205-224.

10. Lusardi A, Mitchell OS (2009) How Ordinary Consumers Make Complex Economic Decisions: Financial Literacy and Retirement Readiness, NBER Working Paper 15350.

11. Lusardi A, Mitchell OS (2011) Financial Literacy and Planning: Implications for Retirement Wellbeing. In: Lusardi A, Mitchell OS, Financial Literacy: Implications for Retirement Security and the Financial Marketplace. Forthcoming, Oxford University Press, UK.

12. Ameriks J, Caplin A, Leahy J (2003) Wealth Accumulation and the Propensity to Plan. Quarterly Journal of Economics 118: 1007-1047.

13. Van Rooij, Maarten CJ, Annamaria Lusardi, Rob JM Alessie (2012) Financia Literacy, Retirement Planning and Household Wealth. Economic Journal 560: 449-478

14. Thaler RH, Bernartzi S (2004) Save More Tomorrow: Using Behavioral Economics to Increase Employee Saving. Journal of Political Economy 112: S164-S187.

15. Bayer P, Bernheim D, Scholz JK (1996) The Effects of Financial Education in the Workplace: Evidence from a Survey of Employers. NBER WP 5655
16. Bernheim D (1998) Financial Illiteracy, Education, and Retirement Saving." In Living with Defined Contribution Pensions, ed. Olivia S. Mitchell and Sylvester Schieber, pp. 38-68, UPenn Press, Philadelphia, USA.

17. Bernheim D, Garrett D (2003) The Effects of Financial Education in the Workplace: Evidence from a Survey of Households. Journal of Public Economics 87: 1487-1519.

18. Clark R, D'Ambrosio M (2002) Saving for Retirement: The Role of Financia Education, TIAA-CREF Institute WP 4-070102-A.

19. Clark R, D'Ambrosio M, McDermed A, Sawant K (2003) Financial Education and Retirement Saving, TIAA-CREF Institute WP 11-020103.

20. Clark R, Schieber S (1998) Factors Affecting Participation Rates and Contribution Levels in 401(k) Plans. In Living with Defined Contribution Pensions, ed Olivia S. Mitchell and Sylvester Schieber, UPenn Press, Philadelphia, USA.

21. McCarthy D, Turner J (2000) Pension Education: Does it Help? Does it Matter? Benefits Quarterly 16: 64-72.

22. Mullainathan, Sendhil, Markus Noth, Antoinette Schoar (2012) The Market for Financial Advice: An Audit Study. NBER Working Paper, 17929.

23. Lachance M, Mitchell OS, Smetters K (2003) Guaranteeing Defined Contribution Pensions: The Option to Buy Back a Defined Benefit Promise. Journal of Risk and Insurance 1: 1-16.

24. Milevsky MA, Promislow SD (2004) Florida's Pension Election: From DB to DC and Back. Journal of Risk and Insurance 3: 381-404.

25. Agarwal S, Driscoll J, Gabaix X, Laibson D (2011) Learning in the Credit Card Market. Federal Reserve Bank of Chicago WP, USA.

26. Campbell JY, Jackson H, Madrian BC, Tufano P (2010) The Regulation of Consumer Financial Products: An Introductory Essay with Four Case Studies. Harvard University Kennedy School WP RWP10-040. 